\title{
EXTENT TO WHICH RISK TRANSFER STRATEGIES AFFECT TRIPLE BOTTOM LINE OF FOOTBALL EVENTS IN NAIROBI COUNTY, KENYA
}

\author{
Peruce Atingo
}

Article DOI: https://doi.org/10.36713/epra7592

DOI No: 10.36713/epra7592

\begin{abstract}
Football organizations have been facing various challenges in Kenya ranging from management problems and event security threats which have been addressed in various continents. However limited has been done to address these challenges in Kenya. Triple bottom line (TBL) measures are critical to any organization and paramount for successful planning and organizing of sports events in today's world. The link between risk management strategies and TBL measures of football events seems to be unclear in Kenya. The study therefore sought to investigate the risk transfer strategies employed by the Footbal events in Kenya. The study hypothesized that the risk transfer strategies do not significantly affect TBL of football events in Nairobi, Kenya. The target population was 882 football stakeholders that comprised Federation of Kenya Football (FKF) organizers, Kenya Premier League (KPL) organizers, officiators, footballers and cheer leaders/fans out of which 268 formed the sample size. Instruments for collecting data included self-administered questionnaires, interview schedules and observation check list. Ten (10) managers of sports management bodies and administrative bodies were interviewed. The study employed both descriptive and explanatory research designs. Simple random sampling and stratified sampling techniques were used to select respondents to participate in the study. Data was analyzed using both descriptive statistics (frequencies, mean and standard deviation) and inferential statistics (linear multiple regression). The study, therefore, recommends the need for football organizations to invest in risk control measures such as providing security in entry and exit points as well as insurance covers for both participants and spectators in order to transfer risks and attain TBL of football events. In addition sports management bodies need to sensitize football stakeholders on various risks that arise in football events. The findings from this study may benefit the Ministry of Sports, Culture and Arts, Football organizing bodies such as Federation of Kenya Football, Kenya Premier League and other football stakeholders in formulation of policies aimed at managing and minimizing risks of football events.
\end{abstract}

KEY WORDS: Risk Transfer Strategies, Triple bottom Line, football event Kenya

\section{INTRODUCTION}

The benefits of Football as a sport include uniting people, improving their self-esteem, increasing a people's pride, raising awareness on disability, inspiring children and promoting wellbeing (Smith, 2009). Football is a complex contact sport that demands physical, physiological, technical and tactical skills; and the risks of injury, lack of or inadequate physical resources, hooliganism and corruption are considerable (Ekblom, 1986; Reilly, 2000). According to O'Brien (2007), planning and organizing of successful sports events require application of risk management strategies-risk control, risk avoidance and risk transfer
Risk transfer is another aspect in which Potts (2008) asserts that risk should be transferred to those who know how to manage it. This would mitigate the higher costs and additional work, usually called risk premium (Potts, 2008). For example, depending on the risk's character, it can be transferred to insurance companies and football clubs, among others. The actors that the risks can be transferred to are, for example, the insurance companies and football clubs among others depending on the risk's character. As a result, this could lead to higher costs and additional work, usually called risk premium (Potts, 2008). It must be recognized that the risk is not eliminated; it is only 


\title{
EPRA International Journal of Multidisciplinary Research (IJMR) - Peer Reviewed Journal
}

\author{
Volume: 7 | Issue: 7 | July 2021|| Journal DOI: 10.36713/epra2013 || SJIF Impact Factor 2021: 8.047 || ISI Value: 1.188
}

transferred to the party that is best able to manage it (PMI, 2004).

Shifting risks and the negative impacts they bring is also an option when the risks are outside the project management's control, for example political issues or labor strikes (Darnall and Preston, 2010). The situation may also consist of catastrophes that are rare and unpredictable in a certain environment. According to Winch (2002) risks that are beyond the management's control should be transferred through insurance policies.

Triple Bottom Line (TBL) brings out the idea that the operation and performance of a given organization or company be measured based on the overall impact it has towards the environment, social capital and economic prosperity (Green Paper 2001). Triple Bottom Line was used for the first time in 1994 by John Elkington in an article in California Management Review and was expanded and explained thoroughly in 1998 in a book entitled Cannibals with Forks: the Triple Bottom Line of 21st Century Business (Gnap, 2012). Elkington argued that organizations should be formulating three different (and quite discrete) bottom lines; first, is the traditional measure of corporate profit; which explains the profit and loss account, second being the one for the organization's 'people account', which is a measure in some shape or form of how socially responsible an organization has been throughout its operations. The third one is the bottom line of the company's 'planet' account, which means measuring how it has impacted the environment (Hindle, 2008).

The Triple Bottom Line strategies could be applied to achieve effective risk management for sustainable football events in Kenya (Gonzalez and Vicente, 2015). According to Savitz (2006), the Triple Bottom Line captures the essence of sustainability by measuring the impact of an organization's activities on the world, including both its profitability and shareholder values and its social, human and environmental capital.

In Kenya, there is a risk of local coaches being relieved of their job in preference to foreign coaches when teams perform poorly and the risk of hooliganism when officiating and coaching are perceived to be poor (Wandera, 2013; Kwalima, 2016; Olilo, 2016). Hooliganism is also blamed on police not creating a buffer zone between fans of competing teams, leading to physical confrontation between the fans (Disanto, 2013). Terrorism has also been cited by the Kenya Premier League (KPL), Federation of Kenya Football (FKF) and Kenya Stadia Management Board as a possible risk, in view of the terrorist attack on
Westgate Mall in Nairobi in September 2013 (Oloo, 2013).

From the foregoing it is essential for stakeholders in risk management for sustainable football events to apply strategies to enhance risk management and ensure sustainability in football events, particularly economic, environmental and social justice sustainability. The study therefore determines the effect of risk transfer on Triple Bottom Line of football events.

$\mathrm{HO}_{1}$ : Risk transfer strategies do not significantly affect Triple Bottom Line of football events in Nairobi County, Kenya

\section{CONCEPT OF TRIPLE BOTTOM LINE IN EVENTS MANAGEMENT}

The concept of Triple Bottom Line is broadly acknowledged as being multidimensional and its various dimensions have brought to light different discourses over time and have often been treated separately. It is important for local authorities to invest in the football events to enjoy the advantage it brings in terms of development (Sparvero and Chalip, 2007). According to Epstein (2009), sustainability framework or model is a powerful opportunity to create enduring value for multiple football stakeholders to be included in planning and organizing risk management activities for sustainable football events.

\section{RISK TRANSFER STRATEGIES}

According to British Government Department for Developing and Executing Government's Public Finance and Economic Policy, risk transfer refers to delivery of services that are contracted out. Swarbrooke et al., (2003) suggest that risk should be transferred from the operator to others. Transferring risks can be undertaken by the conventional method of insurance, or by paying a third party to take the risk (Gray and Larson, 2006; EMBOK, 2000).

It is important for football organizers to have insurance covers for their organizations, for any damages or losses that they may incur in case football events turn chaotic (Nieman et al., 2003; Swaarbrooke, et al., 2003; Gray and Larson, 2006; Palich, et al., 2006). Retained risk is either funded or unfunded (Valsamakis et al., 2004). A risk is unfunded and retained when no provision is made for the financial consequences of a loss. Funded risk, on the other hand, is a planned risk retention where a program or procedure has been set up to fund losses should they occur. De Loach (2000) refers to the capacity to bear risk as the capacity of the organization to undertake such a risk. 
As seen above, risk should be transferred to those who know how to manage it (Potts, 2008). The actors the risks can be transferred to include insurance companies, football clubs among others, depending on the risk's character. As a result this could lead to higher costs and additional work, usually called risk premium (Potts, 2008). It must be recognized that the risk is not eliminated; it is only transferred to the party that is best able to manage it (PMI, 2004). Shifting risks and the negative impacts they bring is also an option when the risks are outside the project management's control, for example political issues or labor strikes (Darnall and Preston, 2010).

Risk situations may also consist of catastrophes that are rare and unpredictable in a certain environment (Winch, 2002). Nieman et al., (2003) suggest that some risks should be retained either because they cannot be identified or because no decision has been made on how to handle them. Risks can be categorized as follows: those with practical means of avoidance, unknown risks, those whose consequences are not serious, those whose consequences of avoiding them are unacceptable and the risks that are actively desired. These should be considered when deciding on a strategy of retention.

Indemnification is a principle borrowed from insurance law. As explained in the Law of Higher Education (Jossey-Bass, 2007). Indemnification is the standard mechanism by which a college assumes liability for risks incurred by its trustees. Under an indemnification agreement, the indemnitor agrees to be responsible for defending any lawsuit filed against the indemnitee (the trustee) and to pay legal fees incurred by the indemnitee and any judgment or settlement arising from the lawsuit.

\section{THEORETICAL FRAMEWORK}

For the sociology of sport to advance, a theory of sport needs to be developed. The propositions are tied to more abstract propositions within exchange and conflict theory. These propositions form a foundation upon which a more comprehensive theory of sport can be built.

\section{TIE TO EXCHANGE AND CONFLICT THEORY}

The study adopted Tie to Exchange and Conflict Theory. According to this theory, there are a number of exchange relationships that are formed between stakeholders such as athletes, fans, coaches, and team owners (Snyder and Spreitzer, 1989). The theory focuses on intrinsic and extrinsic rewards that enhance achievement of satisfaction among stakeholders in sports, including football. Conflict in football could occur when the custom of mutual benefit (exchange relationship) is broken (Turner, 1991).

This is because sports has potential for conflict whenever needs of stakeholders are unmet. Extrinsic rewards include money, prestige and power, which are scarce resources. Once players become aware of scarce resources, then those who miss the rewards may not question the legitimacy of the organization or management plans.

\section{METHODOLOGY}

\section{Research Design}

The study employed descriptive and explanatory research designs. This enabled the researcher to find out the extent to which risk management strategies affect Triple Bottom Line of football events in Nairobi, Kenya. The designs also allowed an in depth inquiry of risk control strategies, risk avoidance strategies and risk transfer strategies from the study population. The research designs also allowed the researcher to use inferential statistics to establish the significant relationships between the dependent and the independent variables in the presentation of the results of this study through description of data results.

The study employed the Krijcie and Morgan Formulae (1970) to determine the sample size because the target population is finite. The following Krijcie and Morgan Formulae was used to determine the sample size.

\section{Data Analysis}

$$
S=\frac{X^{2} N P(1-P)}{d^{2}(N-1)+X^{2} P(1-P)}
$$

Data was analyzed using both descriptive statistics and inferential statistics. Descriptive analysis included computation of mean and frequency, and in form of tables. Inferential was in form simple multiple regression which was used to test the statistical significance of the relationship involving the dependent and independent variables

\section{FINDINGS}

This section gives the analysis, presentation, interpretation, and discussion of results on the mediating effect on the effects of risk transfer strategies on Triple Bottom Line of football events in Kenya.

\section{RISK TRANSFER STRATEGIES}

The results of respondents were collected on their level of agreement with risk transfer indicators. The study found that (24)9.6\% of respondents strongly agreed that they insure property in the football arena against damages, (79)31.6\% agreed majority of (97)38.8\% slightly agreed, (16)6.4\% disagreed while 


\section{EPRA International Journal of Multidisciplinary Research (IJMR) - Peer Reviewed Journal}

Volume: 7 | Issue: 7 | July 2021|| Journal DOI: 10.36713/epra2013 || SJIF Impact Factor 2021: 8.047 || ISI Value: 1.188

(34) $13.6 \%$ strongly disagreed. Results also showed a mean of 3.2 and standard deviation of 1.1 In response whether they insure players against injuries that they may be prone to when playing, (71)28.4\% strongly agreed (60)24\% agreed, (62)24.8\% slightly agreed, (36) $14.4 \%$ disagreed while (21)8.4\% of the respondents strongly disagreed, with a mean of 3.5 and standard deviation of 1.3 consecutively. (35)14\% of respondents strongly agreed that they don't hold organizations liable by allowing companies they organize football events for to sign indemnity agreement forms. (42) $16.8 \%$ agreed, (70)28\% slightly agreed, (77)30.8\% disagreed while (26)10.4\% strongly disagreed. A mean of 2.9 and standard deviation of 1.2 were obtained from the results. In relation to whether they indemnify their organization against players' injuries so that it is players responsible of their own negligence, (35)14\% strongly agreed, (35)14\% agreed, (50)20\% slightly agreed, (39)15.6\% disagreed while (91)36.4\% strongly disagreed. The mean and standard deviation obtained were 2.5 and 1.5 consecutively. A summary of the responses on risk transfer strategies are as shown on table below:

Table 1 Measures of risk transfer strategies

\begin{tabular}{|c|c|c|c|c|c|c|c|c|c|c|c|c|}
\hline \multirow[t]{2}{*}{ Description } & \multicolumn{2}{|c|}{$\begin{array}{c}\text { Strongly } \\
\text { Agree }\end{array}$} & \multicolumn{2}{|c|}{ Agree } & \multicolumn{2}{|c|}{$\begin{array}{c}\text { Slightly } \\
\text { Agree }\end{array}$} & \multicolumn{2}{|c|}{ Disagree } & \multicolumn{2}{|c|}{$\begin{array}{l}\text { Strongly } \\
\text { Disagree }\end{array}$} & \multicolumn{2}{|c|}{ Statistics } \\
\hline & $f$ & $\%$ & $\boldsymbol{F}$ & $\%$ & $f$ & $\%$ & $F$ & $\%$ & $f$ & $\%$ & $M$ & SD \\
\hline $\begin{array}{l}\text { Insure property in } \\
\text { football arena against } \\
\text { damages }\end{array}$ & 24 & 9.6 & 79 & 31.6 & 97 & 38.8 & 16 & 6.4 & 34 & 13.6 & 3.17 & 1.133 \\
\hline $\begin{array}{l}\text { Insure players against } \\
\text { injuries when playing }\end{array}$ & 71 & 28.4 & 60 & 24 & 62 & 24.8 & 36 & 14.4 & 21 & 8.4 & 3.50 & 1.271 \\
\hline $\begin{array}{l}\text { Don't hold org liable } \\
\text { by } \\
\text { companies to sign } \\
\text { indemnity agreement } \\
\text { forms }\end{array}$ & 35 & 14 & 42 & 16.8 & 70 & 28 & 77 & 30.8 & 26 & 10.4 & 2.93 & 1.205 \\
\hline $\begin{array}{l}\text { Indemnify org against } \\
\text { players' injuries }\end{array}$ & 35 & 14 & 35 & 14 & 50 & 20 & 39 & 15.6 & 91 & 36.4 & 2.54 & 1.451 \\
\hline
\end{tabular}

\section{TRIPLE BOTTOM LINE CONSTRUCTS}

The results about triple bottom line indicated that (119)47.6\% of respondents strongly agreed that they consider having dust bins strategically located in different places to counter unnecessary littering in the stadiums. (52)20.8\% agreed (52)20.8\% slightly agreed, (15)6.0\% disagreed while (12)4.8\% strongly disagreed, and a mean of 4.0 and standard deviation of 1.2 was also obtained from the results. In response to whether they create footpaths to ensure people don't step on grass, (104)41.6\% strongly agreed, (71)28.4\% agreed, (29) $11.6 \%$ slightly agreed, (32)12.8\% disagreed while (14)5.6\% strongly disagreed, with a mean of 3.9 and standard deviation of 1.2. In relation to whether they create awareness on the impact pollution of the environment, (100)40.0\% strongly agreed, (50)20.0\% agreed, (40)16\% slightly agreed, (15)6.0\% disagreed while (45)18\% strongly disagreed, with a mean of 3.6 and 1.5 as standard deviation. (120)48\% strongly agreed that they attract greater revenue from sale of admission tickets (84)33.6\% strongly agreed, (24)9.6\% agreed, (12) $4.8 \%$ slightly agreed, (10)4\% disagreed while $4.0 \%$ strongly disagreed. A mean of 4.1 and standard deviation of 1.1 were recorded. In responding to the statement that they encourage authorities to invest in football by offering financial aid, (119)47.6\% strongly agreed, (92)36.8\% agreed, (28)11.2\% slightly agreed, (6) $2.4 \%$ disagreed while (5)2.0\% strongly disagreed. The mean and standard deviation values regarding this were 4.2 and 0.9 consecutively.

Based on ensuring accountability for use of funds for development of football events, (119)47.6\% strongly agreed, (92)36.8\% agreed, (28)11.2\% slightly agreed, (6) $2.4 \%$ disagreed while (5)2.0\% strongly disagreed. Statistical mean value was 4.9 and a standard deviation of 0.8 .while none of the respondents strongly disagree. Based on whether they encourage and develop talents from grass root level, (190)76.0\% strongly agreed, (36)14.4\% agreed, (13)5.2\% slightly agreed (11) $4.4 \%$ disagreed while none of the respondents strongly disagreed. The mean and standard deviation values recorded were 4.6 and 0.8 consecutively. (163)65.2\% of respondents strongly agreed that they encourage development of manpower for future football events, (46)18.4\% agreed, (8)3.2\% slightly agreed, (9)3.6\% disagreed while (24)9.6\% strongly disagreed. The mean was 4.3 and the standard deviation was 1.3 . In responding to the statement that 
they reinforce implementation of health policies for sustainability of football events, (144)57.6\% strongly agreed, (93) $37.2 \%$ agreed, (11)4.4\% slightly agreed, (2) $8.0 \%$ disagreed while none strongly disagreed, with a mean of 4.5 and standard deviation of 0.6. A summary of the responses on Triple bottom line are as shown on table 2 below:

Table 2: Measures of Triple Bottom Line

\begin{tabular}{|c|c|c|c|c|c|c|c|c|c|c|c|c|}
\hline \multirow[t]{2}{*}{ Description } & \multicolumn{2}{|c|}{$\begin{array}{l}\text { Strongly } \\
\text { Agree }\end{array}$} & \multicolumn{2}{|c|}{ Agree } & \multicolumn{2}{|c|}{$\begin{array}{l}\text { Slightly } \\
\text { Agree }\end{array}$} & \multicolumn{2}{|c|}{ Disagree } & \multicolumn{2}{|c|}{$\begin{array}{l}\text { Strongly } \\
\text { Disagree }\end{array}$} & \multicolumn{2}{|c|}{ Statistics } \\
\hline & f & $\%$ & $\boldsymbol{F}$ & $\%$ & $f$ & $\%$ & $\boldsymbol{F}$ & $\%$ & $f$ & $\%$ & $M$ & SD \\
\hline $\begin{array}{l}\text { Dust bins located } \\
\text { strategically }\end{array}$ & 119 & 47.6 & 52 & 20.8 & 52 & 20.8 & 15 & 6.0 & 12 & 4.8 & 4.00 & 1.167 \\
\hline $\begin{array}{l}\text { Footpaths to avoid } \\
\text { stepping on grass }\end{array}$ & 104 & 41.6 & 71 & 28.4 & 29 & 11.6 & 32 & 12.8 & 14 & 5.6 & 3.88 & 1.240 \\
\hline $\begin{array}{ll}\text { Awareness } & \text { on } \\
\text { pollution impact } & \end{array}$ & 100 & 40 & 50 & 20.0 & 40 & 16.0 & 15 & 6.0 & 45 & 18.0 & 3.58 & 1.501 \\
\hline $\begin{array}{l}\text { Revenue from } \\
\text { admission ticket }\end{array}$ & 120 & 48 & 84 & 33.6 & 24 & 9.6 & 12 & 4.8 & 10 & 4.0 & 4.17 & 1.051 \\
\hline $\begin{array}{l}\text { Encourage locals } \\
\text { through financial aid }\end{array}$ & 119 & 47.6 & 92 & 36.8 & 28 & 11.2 & 6 & 2.4 & 5 & 2.0 & 4.26 & 0.895 \\
\hline $\begin{array}{l}\text { Accountability for } \\
\text { use of funds }\end{array}$ & 190 & 76.0 & 36 & 14.4 & 13 & 5.2 & 11 & 4.4 & - & - & 4.62 & 0.778 \\
\hline $\begin{array}{l}\text { Develop talent from } \\
\text { grass root level }\end{array}$ & 163 & 65.2 & 46 & 18.4 & 8 & 3.2 & 9 & 3.6 & 24 & 9.6 & 4.26 & 1.277 \\
\hline $\begin{array}{l}\text { Develop manpower } \\
\text { for future events }\end{array}$ & 144 & 57.6 & 93 & 37.2 & 11 & 4.4 & 2 & 8.0 & - & - & 4.52 & 0.622 \\
\hline $\begin{array}{l}\text { Implement health } \\
\text { policies for } \mathrm{TBL} \text { of } \\
\text { football }\end{array}$ & 140 & 56.0 & 83 & 33.2 & 22 & 8.8 & 5 & 2.0 & - & - & 4.43 & 0.737 \\
\hline
\end{tabular}

Source: Data analysis (2017)

\section{FACTOR ANALYSIS}

Factor analysis attempts to identify underlying variables, or factors, that explain the pattern of correlations within a set of observed variables. Factor analysis is often used in data reduction to identify a small number of factors that explain most of the variance observed in a much larger number of manifest variables (DeCoster, J., 1998). Factor analysis is performed by examining the pattern of correlations (or covariances) between the observed measures. Measures that are highly correlated (either positively or negatively) are likely influenced by the same factors, while those that are relatively uncorrelated are likely influenced by different factors (DeCoster, J. 1998). Factor analysis was carried out for each of the variables to reduce the number of items on each of the variables for ease of presentation, analysis, interpretation and discussion of the most significant factors.

\section{FACTOR ANALYSIS FOR RISK TRANSFER STRATEGIES}

Risk Transfer strategies were captured through statements on a 5- point likert scale. The KMO measure of sampling accuracy indicates a $\mathrm{KMO}=.478$ which is close to 0.5 . This implies the sample size was adequate for the variables entered into analysis. Bartlett's Test of Sphericity that was used to test the adequacy of the correlation matrix yielded a value of 177.155 and an associated level of significance smaller than 0.001, therefore the findings implied that the factor analysis was appropriate for the study as shown in table 4.13 below.

Table 3: KMO and Bartlett's Test of Risk Transfer Strategies

\begin{tabular}{ll} 
Statistics & \\
\hline Kaiser-Meyer-Olkin Measure of sampling Adequacy & 0.478 \\
Bartlers Test of Sphericity Approx Chi-square & 177.155 \\
Df & 6 \\
Sig & $<0.001$ \\
\hline \hline
\end{tabular}


For Risk Transfer Strategies, four factors were computed, but not all the factors were useful in representing the list of variables. Using the criterion of retaining only factors with eigenvalues values of 1 or greater, the first 2 factors were retained for rotation. These 2 factors accounted for $47.45 \%$ and $24.23 \%$ of the total variance respectively. This is a $71.68 \%$ of the total variance attributed to the factors. The remaining factors account for $28.32 \%$ of the variance as shown in table 4.14 below. Thus, a model with two factors may be adequate to represent the data.

Table 4 Total Variance Explained

\begin{tabular}{lllllll}
\hline Component & \multicolumn{2}{c}{$\begin{array}{l}\text { Initial Eigenvalues } \\
\text { Total }\end{array}$} & $\begin{array}{c}\text { \% } \\
\text { Variance }\end{array}$ & of & Cumulative \% & \multicolumn{3}{c}{ Rotation Sums of Squared Loadings } \\
Total & $\begin{array}{l}\text { \% } \\
\text { of }\end{array}$ & Cumulative \% \\
\hline Insurance & 1.898 & 47.454 & 47.454 & 1.802 & 45.061 & 45.061 \\
Indemnity & .969 & 24.231 & 71.685 & 1.065 & 26.623 & 71.685 \\
\hline
\end{tabular}

Extraction Method: Principal Component Analysis.

a. 2 components extracted

Source: Data analysis (2017)

Table 5 below shows the rotated component matrix that presents two factors after Varimax rotation. The clustering of the items in each factor and their wording offer the best clue as to the meaning of the factors. These two components explain a total of variables grouped into each of the two principal components namely: Insurance factors and Indemnification factors. The interactions converged in 2 iterations. The components were rotated using Varimax Criterion to reduce the multi-collinearity and hence account for $100 \%$ of the variance.

Table 5: Rotated Component Matrix (a) of Risk Transfer

\begin{tabular}{llc}
\hline & Insurance factors & Indemnification factors \\
\hline Players' insurance & .911 & \\
Property insurance & .715 & .979 \\
Organizations liability & .672 & \\
Players indemnity & & \\
\hline Extraction Method: Principal Component Analysis. Rotation Method: Varimax with Kaiser Normalization. \\
a Rotation converged in 2 iterations.
\end{tabular}

Source: Data analysis (2017)

Interview results for risk transfer revealed that insurance had entirely helped in alleviating risks in football events as clubs had contracted with various insurance companies that dealt with risk uncertainties that came about whenever there was a match. Indemnification of players and their clubs had also been reinforced by football organizers that ensured transfer of liability to negligent parties.

\section{FACTOR ANALYSIS FOR TRIPLE BOTTOM LINE}

Triple Bottom Line was captured through statements posed that were related to Triple Bottom
Line on a 5-point likert scale. The KMO measure of sampling accuracy indicates a $\mathrm{KMO}=0.614$ which is above the minimum 0.5 . This implies the sample size was adequate for the variables entered into analysis. Bartlett's Test of Sphericity that was used to test the adequacy of the correlation matrix yielded a value of 591.444 and an associated level of significance smaller than 0.001, therefore the findings implied that the factor analysis was appropriate for the study and that there was relationship among the variables. These is shown in table 4.16 below 
Table 6: KMO and Bartlett's Test for Triple bottom Line

\begin{tabular}{ll} 
Statistics & \\
\hline Kaiser-Meyer-Olkin Measure of sampling Adequacy & 0.614 \\
Bartlers Test of Sphericity Approx Chi-square & 591.444 \\
Df & 36 \\
Sig & $<0.001$ \\
\hline \hline
\end{tabular}

Although nine factors were computed for TripleBottom Line, not all the factors were useful in representing the list of variables. Using the criterion of retaining only factors with eigen values of 1 or greater, the first 3 factors were retained for rotation. These 3 factors accounted for $31.03 \%, 17.39 \%$ and $12.86 \%$ of the total variance respectively. This is $61.28 \%$ of the total variance attributed to the three factors. The remaining factors account for $38.72 \%$ of the variance. Thus, a model with three factors may be adequate to represent the data. The information is as shown in table 7 below.

Table 7: Total Variance Explained for Triple Bottom Line

\begin{tabular}{|c|c|c|c|c|c|c|c|}
\hline \multirow[t]{2}{*}{ Component } & \multicolumn{4}{|c|}{ Initial Eigenvalues } & \multicolumn{3}{|c|}{ Rotation Sums of Squared Loadings } \\
\hline & Total & $\begin{array}{l}\% \\
\text { Variance }\end{array}$ & of & $\begin{array}{l}\text { Cumulative } \\
\%\end{array}$ & Total & $\begin{array}{l}\% \text { of } \\
\text { Variance }\end{array}$ & $\begin{array}{l}\text { Cumulative } \\
\%\end{array}$ \\
\hline $\begin{array}{l}\text { Environmental } \\
\text { Awareness }\end{array}$ & 2.793 & 31.029 & & 31.029 & 2.462 & 27.357 & 27.357 \\
\hline Monetary A & 1.565 & 17.386 & & 48.415 & 1.608 & 17.870 & 45.227 \\
\hline Human A & 1.157 & 12.861 & & 61.276 & 1.444 & 16.049 & 61.276 \\
\hline
\end{tabular}

Extraction Method: Principal Component Analysis.

a. 3 components extracted

Source: Data Analysis (2017)

Table 8 below shows the rotated component matrix that presents three factors after Varimax rotation. The clustering of the items in each factor and their wording offer the best clue as to the meaning of the factors. These three components explain a total of variables grouped into each of the three principal

Table 8: Component Matrix (a) Triple Bottom Line

\begin{tabular}{llll}
\hline & $\begin{array}{l}\text { Environmental } \\
\text { awareness factors }\end{array}$ & $\begin{array}{l}\text { Monetary } \\
\text { aspects }\end{array}$ & $\begin{array}{l}\text { Human } \\
\text { aspects }\end{array}$ \\
\hline Creating footpaths & .883 & \\
Creating awareness & .803 & \\
Having dust bins in place & .743 & .813 \\
Investing in football by offering financial aid & & .633 & \\
Attracting greater revenue from the sale of tickets & & .625 & \\
Accountability on the use of funds & & .735 \\
Development of manpower & & .641 \\
Development of talents & & & \\
\hline
\end{tabular}

Extraction Method: Principal Component Analysis. Rotation Method: Varimax with Kaiser Normalization. components namely: Environmental awareness factor, monetary factors and human factors. The interactions converged in 3 iterations. The components were rotated using Varimax Criterion to reduce the multicollinearity and hence account for $100 \%$ of the

Environmental

.813

.625

735

.64 


\title{
EPRA International Journal of Multidisciplinary Research (IJMR) - Peer Reviewed Journal
}

\author{
Volume: 7 | Issue: 7 | July 2021|| Journal D0I: 10.36713/epra2013 || SJIF Impact Factor 2021: 8.047 || ISI Value: 1.188
}

Interview results for Triple Bottom Line revealed that football organizers received funds from gate collections, lottery staging such as betting, from FIFA, and some percentage of funds from the government, among others. The organizers reported that accountability of funds was enhanced through periodically assessing the income expenditure statements. Interview results also revealed that football organizations contributed to Triple Bottom Line by developing man power, which entailed opening football academies especially for children less than 18 years old and encouraging courteous behavior among fans.

\section{INFERENTIAL STATISTICS}

The purpose of inferential statistics is to draw conclusions about a whole population on the basis of information that has been collected on a sample (Rachad, 2003). Inferential statistics are used in generalizing from a sample to a wider population, and in testing hypotheses, i.e. deciding whether the data is consistent with the research prediction. It involves estimating the characteristics of a population from the data obtained from a sample of that population. In this study, Triple Bottom Line was the dependent variable $(\mathrm{Y})$ while the independent variables were risk $\operatorname{control}\left(\mathrm{X}_{1}\right)$, risk avoidance $\left(\mathrm{X}_{2}\right)$ and risk transfer $\left(\mathrm{X}_{3}\right)$.

\section{CONCLUSION}

From the research finding, conclusions were drawn from hypotheses, which were subjected to statistical analysis. This was based on independent variables; Risk control, Risk avoidance and Risk transfer and the dependent variable Triple Bottom Line.

Risk transfer strategies have a positive effect on Triple Bottom Line of football events. This conclusion was reached arising from respondents' agreement to the factors explained by the researcher when collecting data. If football organizers reinforce on insurance strategies and signing of indemnity agreement forms in case of any uncertainty during football games, there is likelihood of having sustainable football events because there is a sense of liability and this makes all parties involved to be very careful when planning and executing any football event.

\section{RECOMMENDATIONS}

$>$ Football organizers should ensure that upon the purchase of tickets by spectators, the tickets must have a clause of indemnity informing them about liability in case of any risks while in the stadiums.

$>$ Football organizers should put systems in place to address insurance for players especially when they are on the pitch.

\section{REFERENCES}

1. Adler, P., and Adler, P. A. (1985). From idealism to pragmatic detachment: The academic performance of college athletes. Sociology of Education, 241250.

2. Alt, J. (1983). Sport and cultural reification: From ritual to mass consumption. Theory, Culture \& Society, 1(3), 93-107.

3. Anshel, M. (1989). The ten commandments of effective communication for referees, judges and umpires. Sports Coach, 12(3), 32-36.

4. Armstrong, E. G. (1996). The commodified 23, or, Michael Jordan as text. Sociology of Sport Journal, 13(4), 325-343.

5. Baker, W. J. (1988). Sports in the western world (Vol. 114). University of Illinois Press.

6. Baldwin, C. (2008). The ref cost us the game: The role of sports commentators and journalists in creating stresses on sports referees. In Power and Place: Refereed Proceedings of the Australian and New Zealand Communication Association Conference. Wellington, July (pp. 9-11).

7. Barclay, J. (2009). Predicting The Costs And Benefits Of Mega-Sporting Events: Misjudgement Of Olympic Proportions?. Economic affairs, 29(2), 62-66.

8. Bar-Eli, M., Levy-Kolker, N., Pie, J.S. \& Tenenbaum, G. (1995). A crisis related analysis of perceived referees' behaviour in competition. Journal of Applied Sport Psychology, 7(1), 63-80.

9. Beckman, L.E. (2006). A system for evaluating emergency response capabilities at a university sporting venue. (Doctoral dissertation). Retrieved from ProQuest Digital Dissertations. Database. (Publication No. AAT 3268436.

10. Casper, J. M., Pfahl, M. E., \& McCullough, B. (2014). Intercollegiate sport and the environment: Examining fan engagement based on athletics department sustainability efforts. Journal of Issues in Intercollegiate Athletics, 7, 65-91.

11. Ciletti, D., Lanasa, J., Ramos, D., Luchs, R., \& Lou, J. (2010). Sustainability communication in North American professional sports leagues: Insights from web-site self-presentations. International Journal of Sport Communication, 3(1), 64-91.

12. Dawson, P., Dobson, S., Goddard, J., \& Wilson, J. (2007). Are football referees really biased and inconsistent?: evidence on the incidence of disciplinary sanction in the English Premier League. Journal of the Royal Statistical Society: Series A (Statistics in Society), 170(1), 231-250.

13. De Coninck, H., Stephens, J. C., \& Metz, B. (2009). Global learning on carbon capture and storage: A call for strong international cooperation on CCS demonstration. Energy Policy, 37(6), 2161-2165.

14. Deloitte (2007). Creating the "Wholly Sustainable Enterprise": A practical Guide to Driving Shareholder Value through Enterprise Sustainability. Deloitte Development LLC., p.3, 
ISSN (Online): 2455-3662

EPRA International Journal of Multidisciplinary Research (IJMR) - Peer Reviewed Journal

Volume: 7 | Issue: 7 | July 2021|| Journal DOI: 10.36713/epra2013 || SJIF Impact Factor 2021: 8.047 || ISI Value: 1.188

http://www.deloitte.com/dtt/cda/doc/

content/Creating/the

wholly/20sustainable/enterprise (1).

15. Giordano, M., \& Shah, T. (2014). From IWRM back to integrated water resources management. International Journal of Water Resources Development, 30(3), 364-376.

16. Goldberg, J. (2000). Sporting diplomacy: Boosting the size of the diplomatic corps. Washington Quarterly, 23(4), 63-70.

17. Goodland, 2001; Tourism development and the Environment: Beyond Sustainability? London: Earthscan.

18. Grant Jr, T. J. (2014). Green monsters: Examining the environmental impact of sports stadiums. Vill. Envtl. LJ, 25, 149.

19. Groot, L. (2005). Referees among most important players in soccer tournaments. Journal of Sport and Social Issues, 29(4), 437-442.

20. Hamedani Amin Zeinal (2014) Methodology and statistical analysis of sustainable transportation criteria for certification systems. Dissertation zur Erlangung des Grades der Bergischen Universität Wuppertal. urn:nbn:de:hbz:468-20141007-1123148 [http://nbnresolving.de/urn/resolver.pl?urn $=$ urn $\% 3 \mathrm{Anbn} \% 3 \mathrm{~A}$ de\%3Ahbz\%3A468-20141007-112314-8]

21. Holt, N. L., Tink, L. N., Mandigo, J. L., \& Fox, K. R. (2008). Do youth learn life skills through their involvement in high school sport? A case study. Canadian Journal of Education/Revue canadienne de l'éducation, 281-304.

22. Inoue, Y., \& Kent, A. (2012). Sport teams as promoters of pro-environmental behavior: An empirical study. Journal of Sport Management, 26(5), 417-432.

23. Jennings, W. (2008). London 2012: Olympic risk, risk management, and Olymponomics. John Liner Review, 22(2), 39-45.

24. Jennings, $W$., and M. Lodge. 2009. "Governing mega-events: Tools of security management for the London 2012 Olympic Games and FIFA 2006 World Cup in Germany." ESRC Centre for Analysis of Risk and Regulation Discussion Paper, London School of Economics and Political Science No. 55: 1-25.

25. John Elkington (1997) Sustainable tourism in protected areas: Guidelines for planning and management. Gland: IUCN.

26. Kain, J.-H. (2000): Urban support systems-Social and technical, socio-technical or sociotechni-cal. Gothenburg.

27. Kartakoullis, N. L., Vrontis, D., Thrassou, A., \& Kriemadis, T. (2013). Strategic resource planning for football clubs. Journal for International Business and Entrepreneurship Development, 7(1), 1-20.

28. Maloy, B. P. (1991). Planning for effective risk management: A guide for stadium and arena management. Marq. Sports LJ, 2, 89.
29. Manchester United Foundation. (2014). United for UNICEF. Retrieved from http://www.mufoundation.org

30. Martens, R. (1975). Social psychology and physical activity. New York: Harper and Row.

31. McCullough, B. P. (2013). Identifying the influences on sport spectator recycling behaviours using the theory of planned behaviour. International Journal of Sport Management and Marketing, 14(1-4), 146-168.

32. McCullough, B. P., \& Cunningham, G. B. (2010). A conceptual model to understand the impetus to engage in and the expected organizational outcomes of green initiatives. Quest, 62(4), 348363.

33. Peppard, V., \& Riordan, J. (1993). Playing politics: Soviet sport diplomacy to 1992. JAI Press Inc.

34. Pfahl, M. E. (2010). Strategic issues associated with the development of internal sustainability teams in sport and recreation organizations: $A$ framework for action and sustainable environmental performance. International Journal of Sport Management, Recreation and Tourism, 6, 37-61.

35. OECD Observer (Interviewer) \& Nene, $N$. (Interviewee). (2013). After the final: Reflections on South Africa's soccer World Cup [Interview transcript]. Retrieved from OECD Observer Web site:

http://www.oecdobserver.org/news/fullstory.php/ai d/4181/After_the final.html

36. Thomas J. Grant Jr., Green Monsters: Examining the Environmental Impact of Sports Stadiums, 25 Vill. Envtl. L.J. 149 (2014). Available at: http://digitalcommons.law.villanova.edu/elj/vol25/i ss $1 / 6$

37. Turner, J.H. (1991). The structure of sociological theory (5th ed.). Belmont, California: Wadsworth.

38. U.S. Green Building Council. (2011a). About USGBC. Retrieved from http://www.usgbc.org

39. United Nations. (2014). Sport for development and peace. Retrieved from http://www.un.org

40. Wann, D. L. (2006). The causes and consequences of sport team identification. Handbook of sports and media, 331-352.

41. Weber, M. (1968). Economy and Society New York: Bedminster Press

42. Young, K. (2002). Standard deviations: An update on North American sports crowd disorder. Sociology of Sport journal, 19(3), 237 275. 